\title{
'Endura' caucasian clover: progress towards commercial seed production
}

\author{
B.R. GUY \\ Kimihia Research Centre, PO Box 939, Christchurch
}

\begin{abstract}
A series of seed production trials was established at Kimihia Research Centre, Lincoln, Canterbury to investigate row spacing sowing date and sowing rate requirements for Endura, the hexaploid cultivar of caucasian clover. In 1991 a trial with $30 \mathrm{~cm}$ or $45 \mathrm{~cm}$ row spacings with a sowing rate of $8 \mathrm{~kg} / \mathrm{ha}$ coated inoculated seed was used. Although there were no significant differences in the first year $(101 \mathrm{~kg} / \mathrm{ha} \mathrm{cf.} 111 \mathrm{~kg} / \mathrm{ha})$, the $45 \mathrm{~cm}$ row spacing yielded significantly higher than the $30 \mathrm{~cm}$ row spacing, in the second year $(709 \mathrm{~kg} / \mathrm{ha}$ cf. 371 $\mathrm{kg} / \mathrm{ha}$ ). Wider rows produced more flowers per unit area $-448 \mathrm{~m}^{-2}$ for $45 \mathrm{~cm}$ compared with 288 for $30 \mathrm{~cm}$. In 1992 a sowing rate trial was established using $2 \mathrm{~kg}$ or $6 \mathrm{~kg} / \mathrm{ha}$ of coated and inoculated seed in $45 \mathrm{~cm}$ row spacings. The lower sowing rate treatment of $2 \mathrm{~kg} / \mathrm{ha}$ produced a significantly higher seed yield, of $208 \mathrm{~kg} / \mathrm{ha}$. The effect of sowing date (December, January, February) on seed yields was investigated. All sowing date treatments were sown at $6 \mathrm{~kg} / \mathrm{ha}$ in $45 \mathrm{~cm}$ rows. The highest seed yield of $126 \mathrm{~kg} / \mathrm{ha}$ was from January sowing. Weed seed content in the field-dressed samples harvested was associated with sowing date and decreased with each progressive sowing. The results indicate a strong negative correlation between plant density and seed yield. With early sowing, weed control is vitally important for successful seed production.
\end{abstract}

Keywords: row spacing, seed yield, sowing date, sowing rate, Trifolium ambiguum

\section{Introduction}

Caucasian clover (Trifolium ambiguum M. Bieb) is a very persistent temperate legume with similarities to both white and red clover. It differs from both these species by producing deep, thick tap-roots and a dense network of underground rhizomes. These rhizomes form daughter plants, giving caucasian clover the ability to 'creep' through the pasture, even under very hard grazing.
This ability to survive, persist and recover under harsh conditions of climate and grazing pressure has created considerable interest in New Zealand (Allan \& Keoghan 1994; Daly \& Mason 1987), Australia (Hill \& Mulcahy 1993; Yates 1993) and USA (Ehlke, pers. comm 1993).

However, reliable seed supply has been one of the main factors limiting further evaluation work and commercialisation. To date actual seed yields have ranged from $0-200 \mathrm{~kg} / \mathrm{ha}$. Experimental seed yields from plot trials have also been variable within the range 40-900 kg/ha (Bryant 1974; Voloshenko et al. 1979; Stewart \& Daly 1980; Efendi 1993).

It has been suggested (Hampton et al. 1990; Hill et al. 1993) that factors contributing to this erratic seed yield are the inherently poor flowering of the older cultivars such as Monaro and the lack of application of appropriate seed production technology such as appropriate row spacing, sowing rate, weed control, rhizobia and water management.

To address some of these agronomic issues three trials were established at Kimihia Research Centre, Lincoln, Canterbury between 1991 and 1993 to investigate row spacing, sowing rate and sowing time. The newly released hexaploid cultivar Endura was used. Endura was bred for uniform flowering, higher seed yield potential and good agronomic performance (Norriss, pers.comm 1993).

\section{Materials and methods}

Three trials were sown at Kimihia Research Centre, Lincoln, Canterbury on a Templeton silt loam soil. Soil tests taken before drilling showed fertility levels of $\mathrm{P} 27 \mathrm{ppm}, \mathrm{pH} \mathrm{5.8}$, and an annual average rainfall of $660 \mathrm{~mm}$. All trials were fully randomised with four replicates, with irrigation applied twice during the growing season. Weed control included Treflan (2 1/ha) applied pre-plant, with follow-up treatments of Basagran ( $31 /$ ha) and paraquat ( $21 /$ ha) as required by the weed spectrum.

All seed was coated. The coating contained lime and trace elements (including Mo), binding adhesives and rhizobia (this coating has a weight increase factor of $1.75 x)$. 


\section{Row spacing trial}

A 2-year trial was established with $30 \mathrm{~cm}$ and $45 \mathrm{~cm}$ row spacings (Table 1). Mature seedheads, which had turned brown at harvest, were counted from a $1 \mathrm{~m}$ row length just before harvest each year. In the first year, harvesting followed desiccation (2 1/ha Reglone). Harvesting was 3-4 days later using a rotary mower $(45 \mathrm{~cm}$ wide) to harvest a strip $5 \mathrm{~m}$ long in each plot. In the second year, hand harvesting enabled maximum potential seed yield to be obtained.

\section{Sowing rate and sowing date trials}

Three sowing dates (22 December 1992, 26 January 1993 and 25 February 1993) and two sowing rates (2 and $6 \mathrm{~kg} / \mathrm{ha}$ ) were compared. Experimental conditions are described in Table 1.

Harvesting was carried out using a rotary mower cutting a strip $45 \mathrm{~cm} \times 5 \mathrm{~m}$ from each plot. In all three trials, the seed was threshed with a Peltz thresher and cleaned on a Pekus dresser to commercial standards.

In the sowing date trial, the weed seed content was recorded to determine the level of weed infestation at each sowing time.

\section{Results and discussion}

\section{Row spacing}

In the first year there was no significant difference in seed yield between $30 \mathrm{~cm}$ and $45 \mathrm{~cm}$ row spacing (Table 2).

However in the second year (hand harvested), the $45 \mathrm{~cm}$ row spacing yielded $709 \mathrm{~kg} / \mathrm{ha}$, double the $30 \mathrm{~cm}$ row spacing yield of $371 \mathrm{~kg} /$ ha (Table 2).

Although flower numbers in the second year showed no significant difference, there was a trend for increasing flower numbers and seed yield with a wider row spacing. It appears that caucasian clover requires space for plant development and maximum seed yield. Possible factors include a requirement for physical space, and a requirement for high levels of water and nutrients.

However, a balance has to be found between maximum flower production per unit area and likely harvest efficiency. Increasing space between plants may decrease harvest efficiency owing to the inability to capture seedheads which lie on the ground between rows.
Table 2 Effect of row spacing on the seed yield of Endura caucasian clover over 2 years.

\begin{tabular}{|c|c|c|c|c|}
\hline \multirow{2}{*}{$\begin{array}{l}\text { Row width } \\
\qquad(\mathrm{cm})\end{array}$} & \multicolumn{2}{|c|}{------ Year 1\# ------ } & \multicolumn{2}{|c|}{-------- Year 2 \#\# -------- } \\
\hline & $\begin{array}{c}\text { Seedyield } \\
\mathrm{kg} / \mathrm{ha}\end{array}$ & Flowers $/ \mathrm{m}^{2}$ & $\begin{array}{c}\text { Seed yield } \\
\mathrm{kg} / \mathrm{ha}\end{array}$ & Flowers $/ \mathrm{m}^{2}$ \\
\hline 45 & $111 a$ & $184 a$ & $709 a$ & $448 a$ \\
\hline 30 & $101 \mathrm{a}$ & $214 a$ & $371 \mathrm{~b}$ & $288 a$ \\
\hline LSD (5\%) & 31 & 108 & 266 & 357 \\
\hline
\end{tabular}

Means with the same letter do not differ at $P \leq 0.05$

\# Harvested with rotary mower

\#\# Hand harvested

The differences in yield between the first and second years were attributed partly to harvesting techniques and an increase in seed set. However, the increase in flowers $/ \mathrm{m}^{2}$ in second year indicates that the highest seed yields are likely to come from second-year crops.

\section{Sowing rate}

A significant $65 \%$ increase in seed yield was recorded from the $2 \mathrm{~kg} /$ ha sowing rate compared with $6 \mathrm{~kg} / \mathrm{ha}$ (Table 3).

This result supports the results of the row spacing trial, that caucasian clover requires room to fully develop branches and flowers for maximum seed yield.

Table 3 Effect of sowing rate on seed yield of Endura caucasian clover in a first year crop.

\begin{tabular}{cc}
\hline $\begin{array}{c}\text { Sowing rate } \\
\mathrm{kg} / \mathrm{ha}\end{array}$ & $\mathrm{kg} / \mathrm{ha}$ \\
\hline $2 \mathrm{~kg}$ & $208 \mathrm{a}$ \\
$6 \mathrm{~kg}$ & $126 \mathrm{~b}$ \\
$\mathrm{LSD}(5 \%)$ & 78.5 \\
\hline
\end{tabular}

Means with the same letter do not differ at $\mathrm{P} \leq 0.05$ 


\section{Sowing date}

Of the three sowing dates used, the highest seed yield of $126 \mathrm{~kg} / \mathrm{ha}$ was recorded from the 26 January sowing (Table 4). Weed seed content, mainly white clover, decreased from $41 \mathrm{~kg} / \mathrm{ha}$ with the 22 December sowing to $5 \mathrm{~kg} /$ ha for the 25 February sowing (Table 4). The earlier sowings produced lower seed yields and were associated with increased weed competition. Later sowings of Endura were unable to reach sufficient size before winter and so were unable to achieve maximum seed yield potential the following summer. Trial results and farmer observations indicate that achieving maximum seed yield depends on controlling weeds, particularly white clover, as they become very competitive in the crop. Paddock selection, using buried seed analysis for white clover, will be a prerequisite in maximising yields.

Table 4 Effect of sowing date on seed yield of Endura caucasian Clover.

\begin{tabular}{lcc}
\hline Sowing Date & $\begin{array}{c}\text { Seed yield } \\
\mathrm{kg} / \mathrm{ha}\end{array}$ & $\begin{array}{c}\text { Weed seed } \\
\mathrm{kg} / \mathrm{ha}\end{array}$ \\
\hline 22 December 1992 & $67 \mathrm{~b}$ & $41 \mathrm{a}$ \\
26 January 1993 & $126 \mathrm{a}$ & $27 \mathrm{ab}$ \\
25 February 1993 & $94 \mathrm{~b}$ & $5 \mathrm{~b}$ \\
LSD (5\%) & 30 & 25 \\
\hline
\end{tabular}

Means with the same letter do not differ at $\mathrm{P} \leq 0.05$

\section{Conclusions}

- Time of sowing is critical and needs to be completed to allow plants to become established and well developed before the onset of winter. Row spacing of $45 \mathrm{~cm}$ at $2 \mathrm{~kg} / \mathrm{ha}$ coated seed appears to be the best strategy to maximise flower numbers and produce high seed yields.

- Potential yields of $700 \mathrm{~kg} / \mathrm{ha}$ are possible in the second year, with $400-500 \mathrm{~kg} / \mathrm{ha}$ a commercial reality.

- Weed control, particularly of white clover, is essential if maximum seed yields of Endura caucasian clover are to be achieved. Paddocks with a low white clover buried seed content should be selected.
- Future research into planting methods, fertiliser requirements, irrigation and multi-harvest cropping techniques are being investigated.

\section{ACKNOWLEDGEMENT}

I would like to thank M.G. Norriss (Kimihia Research Centre), K. Widdup and P. Clifford (AgResearch, Lincoln), and N.J. Ehlke (University of Minnesota, USA) for their comments over the three years of the trials.

\section{REFERENCES}

Allan, B.E.; Keoghan, J.M. 1994. More persistent legumes and grasses for oversown tussock country. Proceedings of the New Zealand Grassland Association 56: 143-147.

Bryant, W.G. 1974. Caucasian clover (Trifolium ambiguum, M. Bieb): A review. Journal of the Australian Institute of Agricultural Science 40: $11-9$.

Daly, G.T.; Mason, C.R. 1987. Performance of caucasian clover and zig zag clover. Proceedings of the New Zealand Grassland Association 48: 151-156.

Efendi, F. 1993. A study of vegetative and reproductive development in caucasian clover (Trifolium ambiguum, M. Bieb). cv Monaro. Seed Technology Centre, Massey University.

Hampton, J.G.; Hill, M.J.; Rolston, M.P. 1990. Potential for seed production of non-traditional herbage species in New Zealand. Proceedings of the New Zealand Grassland Association 52: 65-70.

Hill, M.J.; Mulcahy, C.M. 1993. Caucasian clover (Trifolium ambiguum M.Bieb). A position paper for Australia and New Zealand in 1993. Alternative Pasture Legumes 1993: 88-93.

Stewart A.V.; Daly, G.T. 1980. Growth of an established stand of Trifolium ambiguum in fertile lowland environment. New Zealand journal of experimental agriculture 8: 255-257.

Voloshenko, E.K.; Skripchinski, V.V.; Scheuchank, G.T. 1979. Trifolium ambiguum M. Bieb. Herbage abstracts 49: 722 .

Yates, J.J. 1993. Growth and persistence of Trifolium ambiguum on "High Country" in Tasmania, Australia. Proceedings of XVII International Grassland Congress: 1791-1792. 
